\title{
Sistem Informasi Manajemen Perangkat Elektronik Berbasis Web
}

\author{
Budi Sunaryo ${ }^{1}$, M. Ilhamdi Rusydi*1, Abdul Manab ${ }^{1}$, Amirul Luthfi ${ }^{1}$, Rudi1 ${ }^{1}$,Trisya Septiana1 \\ ${ }^{1}$ Teknik Elektro, Fakultas Teknik, Universitas Andalas \\ (corresponding author) rilhamdi@ft.unand.ac.id*
}

\begin{abstract}
Internet of Things (IOT) that implemented on smarthome allows user to control and monitor any electronic device via internet connection. Smarthome system that support synchronization of on/off condition data of electronic device between database and controlling using switch, web application, and time scheduling was designed in this research. This systems was implemented on a web-based information system named Sistem Informasi Manajemen Perangkat Elektronik (SIMPLE) that using several tools such as Apache, MySQL, and PHP on the software side, while Arduino Mega and Raspberry Pi were used on the hardware side. Agile modeling method with scrum approach was used on designing the system. The result showed that SIMPEL application provided ease on controlling electronic device at home. People could monitor and control the electrical devices at home from other places as long as the internet connection is available.
\end{abstract}

Keyword- information system, internet of things, smarthome.

Intisari-Smarthome merupakan salah satu implementasi konsep Internet of Things (loT) yang memungkinkan untuk memonitor dan mengendalikan perangkat elektronik melalui jaringan internet. Pada penelitian ini dirancang sebuah sistem smarthome yang mendukung sinkronisasi pengontrolan hidup dan matinya perangkat elektronik melalui sakelar, aplikasi web dan penjadwalan waktu dengan database. Untuk mendukung sistem tersebut digunakan beberapa aplikasi pendukung seperti Apache, MySQL, dan PHP serta perangkat keras berupa Arduino dan Raspberry Pi. Sementara itu, metode pemodelan Agile dengan pendekatan Scrum digunakan dalam perancangan sistem ini. Penelitian ini diimplementasikan dalam sebuah sistem informasi manajemen perangkat elektronik berbasis web yang bernama SIMPEL. Aplikasi SIMPEL memberikan kemudahan dalam mengendalikan perangkat elektronik yang ada di rumah.

Kata Kunci- sistem informasi, internet of things, smarthome.

\section{PENDAHULUAN}

Internet of Things (IOT) merupakan sebuah konsep teknologi yang akan terus berkembang sejalan dengan perkembangan teknologi informasi. Konsep loT mengacu kepada kombinasi dan relasi antara teknologi perangkat keras pada perangkat elektronika dengan teknologi informasi pada sistem informasi, sehingga memudahkan berbagai benda dapat saling berkomunikasi dan bertukar informasi dengan benda lainnya. Konsep loT dapat diaplikasikan dalam berbagai aspek kehidupan manusia, contohnya pengembangan loT untuk aplikasi rumah atau yang dikenal dengan Smarthome yang mana setiap perangkat di rumah dapat saling terhubung dengan adanya internet[1],[2],[3].

Smarthome telah menjadi topik penelitian yang cukup pesat perkembangan belakangan ini. Adapun contoh penelitian yang terkait adalah pengontrolan dan monitoring perangkat elektronik dilakukan dari jarak jauh menggunakan web server untuk menghidupkan dan mematikan perangkat elektronik yang dikonfigurasi pada komputer server dan juga sistem pengontrolan dan monitoring perangkat yang terhubung jaringan GSM dan teknologi internet[4],[5],[6] yang mana pada sistem tersebut hanya mengakomodir pengontrolan dari sisi website saja dan juga tidak mengakomodir sistem penjadwalan. Pada penelitian ini akan dirancang sebuah sistem yang tidak hanya dapat mengontrol dan memonitoring perangkat elektronik tetapi juga memiliki kemampuan untuk sinkronisasi pengontrolan melalui sakelar dan aplikasi web. Dengan menggunakan sistem ini juga memungkinkan pengguna untuk mengatur penjadwalan hidup dan matinya perangkat. Penelitian ini diimplementasikan dalam sebuah sistem informasi manajemen berbasis web yang bernama SIMPEL (Sistem Informasi Manajemen Perangkat Elektronik) yang merupakan subsistem dari BEMS (Building Energy Management System).

\section{SISTEM INFORMASI}

Sistem informasi manajemen perangkat elektronik merupakan sebuah sistem yang memuat sejumlah informasi mengenai lokasi, kondisi, serta pengaturan perangkat elektronik. Sistem yang dirancang menerapkan metode pemodelan Agile dengan pendekatan Scrum. Metode ini digunakan untuk dokumentasi dan pemodelan perangkat lunak 
agar dapat diaplikasikan pada software development project secara efektif[7],[8]. Sistem ini juga didukung oleh beberapa aplikasi diantaranya :

1) Apache

Apache adalah sebuah nama web server yang bertanggung jawab pada request-response HTTP dan logging informasi secara detail. Selain itu, Apache juga diartikan sebagai suatu web server yang kompak, modular, mengikuti standar protokol HTTP. Apache memiliki fitur-fitur canggih seperti pesan kesalahan yang dapat dikonfigurasi dan autentifikasi database. Apache juga didukung oleh sejumlah antarmuka pengguna berbasis grafik yang memungkinkan penanganan server menjadi mudah. Apache menyimpan sebuah log yang mana terdapat 2 buah log, yaitu error log dan access log. Error log berfungsi untuk menyimpan pesan kesalahan pada web server, sedangkan access log menyimpan data-data yang berupa IP pengakses web, time-stamp, status kode, besar bandwidth yang diakses, keterangan lokasi yang diakses, serta engine yang digunakan.

2) MySQL

Dalam sebuah sistem manajemen database diperlukan sebuah perangkat lunak yang dapat mengelola data dalam jumlah yang besar dan dapat memanipulasi data secara lebih mudah. MySQL merupakan salah satu perangkat lunak yang memilki performa yang lebih baik dalam penggunaan media penyimpanan, integritas, independensi, sentralisasi dan keamanan. Setiap data perangkat yang akan ditampilkan dalam browser akan disimpan dan diproses dalam database.

3) PHP

Untuk mendukung sistem diperlukan sebuah website dinamis yang dapat menyesuaikan tampilan konten, menyimpan data ke dalam database. Sebuah website dinamis dapat diaplikasikan menggunakan bahasa pemrograman PHP untuk mengolah isi data dari website tersebut yang akan dilihat oleh pengguna. Keluaran dari sistem ini diakses melalui browser yang telah dirancang menggunakan bahasa pemrograman ini.

\section{MetOdE}

Penelitian ini disusun dengan beberapa tahapan proses. Gambar 1 menampilkan tahapan proses pengembangan sistem berdasarkan metode Agile. Tahapan proses tersebut disesuaikan dengan kebutuhan dari pengembangan SIMPEL berdasarkan metode Agile dengan pendekatan Scrum. Kelebihan dari metodologi ini yaitu dapat melakukan adaptasi terhadap setiap perubahan, efisiensi waktu dan mengurangi resiko kesalahan pada sistem yang dirancang[9]. Metode Agile terdiri atas empat tahapan proses, diantaranya perencanaan, analisis dan desain, serta coding assembling dan testing.

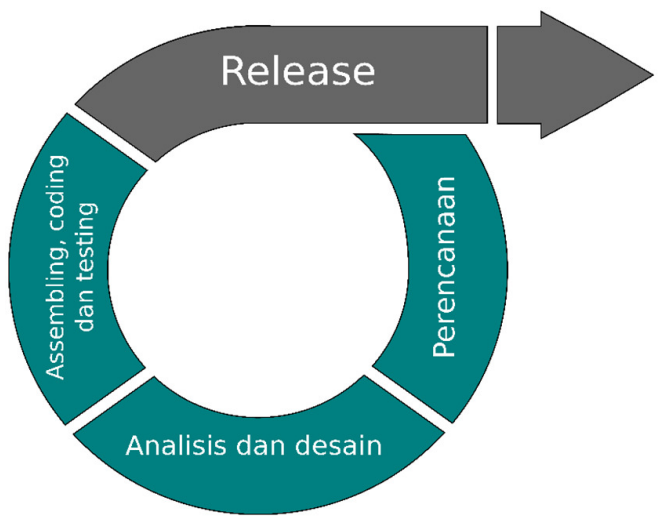

Gambar. 1. Tahapan Proses Pengembangan Sistem Manajemen Perangkat Elektronik Berdasarkan Metode Agile

\section{A. Perencanaan}

Tahapan perencanaan memuat kebutuhan awal yang diperoleh dari pengumpulan data, studi literatur, pemilihan alat, pemilihan perangkat keras dan perangkat lunak pendukung. Tahapan ini memiliki peranan dalam mengidentifikasi kebutuhan dari keseluruhan sistem. Tahapan ini membentuk sebuah skema sistem yang memuat komponen-komponen aplikasi pendukung dan dapat diimplementasikan pada aplikasi berbasis web. Sehingga aplikasi sistem yang dirancang dapat lebih fleksibel sesuai kebutuhan seperti aplikasi berbasis web yang dapat beradaptasi terhadap perkembangan teknologi informasi.

Gambar 2 menampilkan skema sistem informasi manajemen perangkat elektronik. Sistem ini menggunakan database server MySQL di internet dengan perantara Apache sebagai web server dan PHP sebagai server side scripting. Secara keseluruhan, semua perangkat elektronik terhubung dengan internet melalui beberapa perangkat seperti sakelar, modul SIMPEL, Arduino, dan Raspberry Pi. Pada Arduino dan Raspberry Pi dimasukan sebuah bahasa pemograman yang 
mampu mengirim, menerima, dan mengolah informasi hidup dan matinya perangkat elektronik. Untuk memudahkan pengguna, maka dibangunlah sebuah aplikasi berbasis web yang dapat diakses melalui browser pada komputer atau smartphone, sehingga perangkat elektronik dapat dikontrol, dimonitoring, dan diatur sesuai kebutuhan. Fleksibilitas manajemen sistem ini memiliki tiga aksi penting dalam menghidupkan atau mematikan perangkat elektronik diantaranya yaitu melalui aplikasi web, kontrol sakelar, dan penjadwalan dari hari minggu hingga hari sabtu. Ketiga aksi ini dapat melakukan sinkronisasi data hidup atau mati perangkat pada database di MySQ

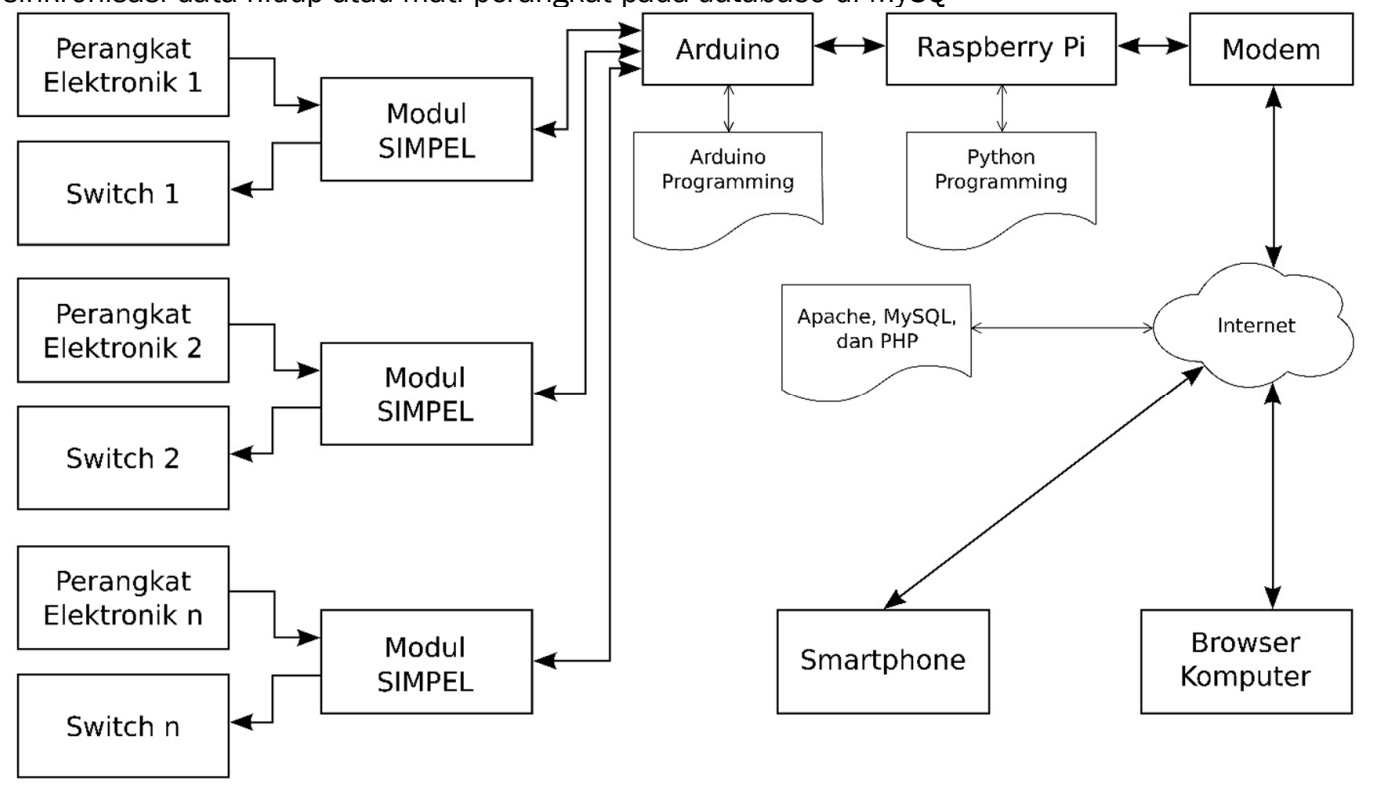

Gambar. 2. Skema Sistem Informasi Manajemen Pengontrolan Perangkat Elektronik Berbasis Web

Secara keseluruhan, semua perangkat elektronik terhubung dengan internet melalui beberapa perangkat seperti switch, SIMPEL modul, Arduino, dan Raspberry Pi. Beberapa perangkat tersebut ditanamkan sebuah program yang mampu memberikan informasi hidup dan mati perangkat. Bahasa pemrograman yang dipakai yaitu Arduino Programming dan Python. Informasi dalam bentuk data akan dikirimkan dan dikumpulkan dalam sebuah database server MySQL di internet dengan perantara Apache sebagai Web Server dan PHP sebagai Server Side Scripting.

Untuk memudahkan pengguna, maka dibangunlah sebuah aplikasi berbasis web yang dapat diakses melalui browser pada komputer atau smartphone, sehingga perangkat elektronik dapat dikontrol, dimonitoring, dan diatur sesuai kebutuhan. Fleksibilitas manajemen sistem ini memiliki tiga aksi penting dalam menghidupkan atau mematikan perangkat elektronik diantaranya yaitu melalui aplikasi web, kontrol switch, dan time schedule dari hari minggu hingga hari sabtu. Ketiga aksi ini dapat melakukan sinkronisasi data hidup atau mati perangkat pada database di MySQL.

\section{B. Analisis dan Desain}

Tahapan kedua adalah analisis dan desain yang memuat pemodelan sebagai gambaran sebuah sistem. Permodelan sistem menggunakan Unified Modeling Language (UML) untuk kemudahan pengerjaan pada tahap selanjutnya. Beberapa permodelan UML digambarkan dalam beberapa diagram sebagai berikut :

1) Diagram Use Case

Diagram use case Sistem Informasi Manajemen Perangkat Elektronik (SIMPEL) ini memuat informasi tentang pengguna dan aplikasi terhadap sebuah sistem. Gambar 3 menampilkan diagram use case dari SIMPEL. Pada diagram ini SIMPEL APP sebagai sebuah aktor karena memiliki peranan penting dalam verifikasi login pengguna, menampilkan kondisi hidup dan mati perangkat elektronik, serta sinkronisasi data hidup dan mati sakelar terhadap database. 


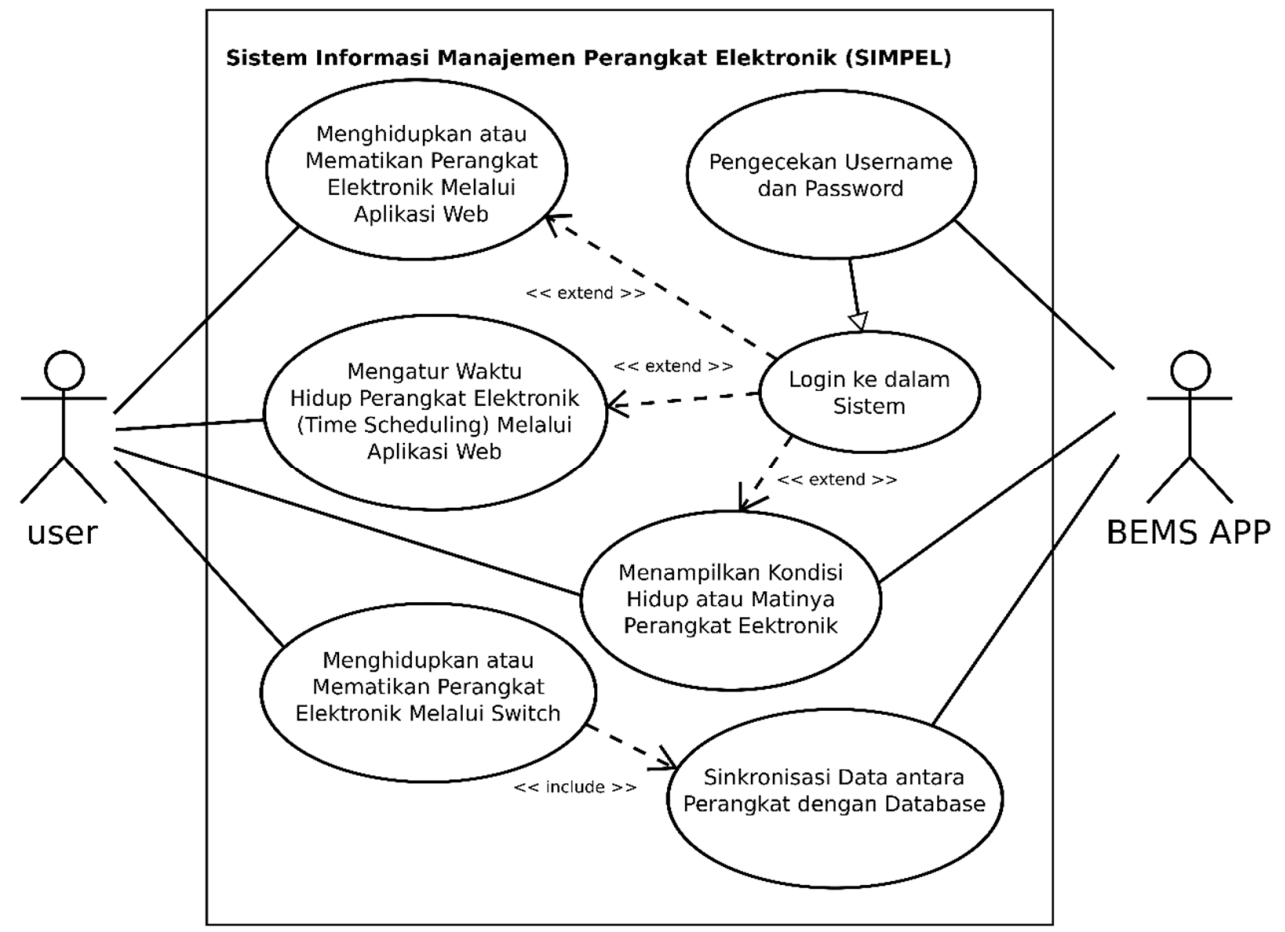

Gambar. 3. Diagram Use Case SIMPEL

2) Diagram Kelas

Diagram kelas pada SIMPEL menggambarkan struktur sistem dalam bentuk kelas-kelas dan memiliki relasi antara kelasnya. Gambar 4 menampilkan class diagram dari sistem manajemen informasi perangkat elektronik. Setiap kelas saling terhubung melalui atribut yang nilainya sama.

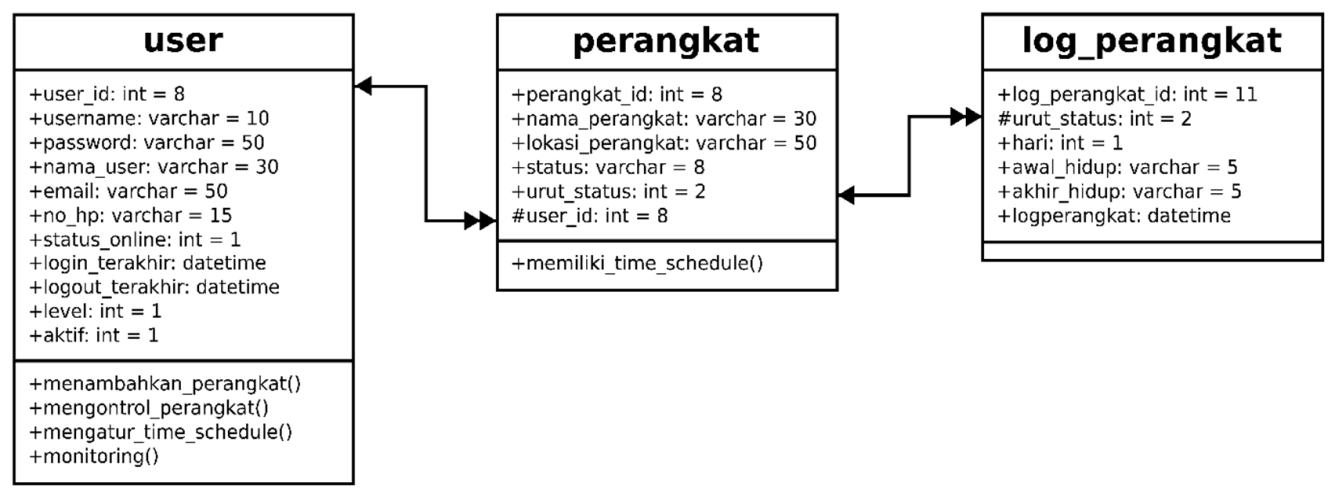

Gambar. 4. Diagram Kelas SIMPEL

\section{3) Diagram Aktifitas}

Diagram aktifitas pada SIMPEL menggambarkan aliran proses pengaturan hidup dan matinya perangkat elektronik. Gambar 5 menampilkan diagram aktiftas dari SIMPEL yang memiliki tiga peranan penting, diantaranya adalah kontrol hidup dan mati perangkat elektronik, sinkronisasi kondisi hidup dan mati perangkat dengan database, serta pengaturan penjadwalan hidup dan mati perangkat elektronik dari hari minggu hingga hari sabtu. 


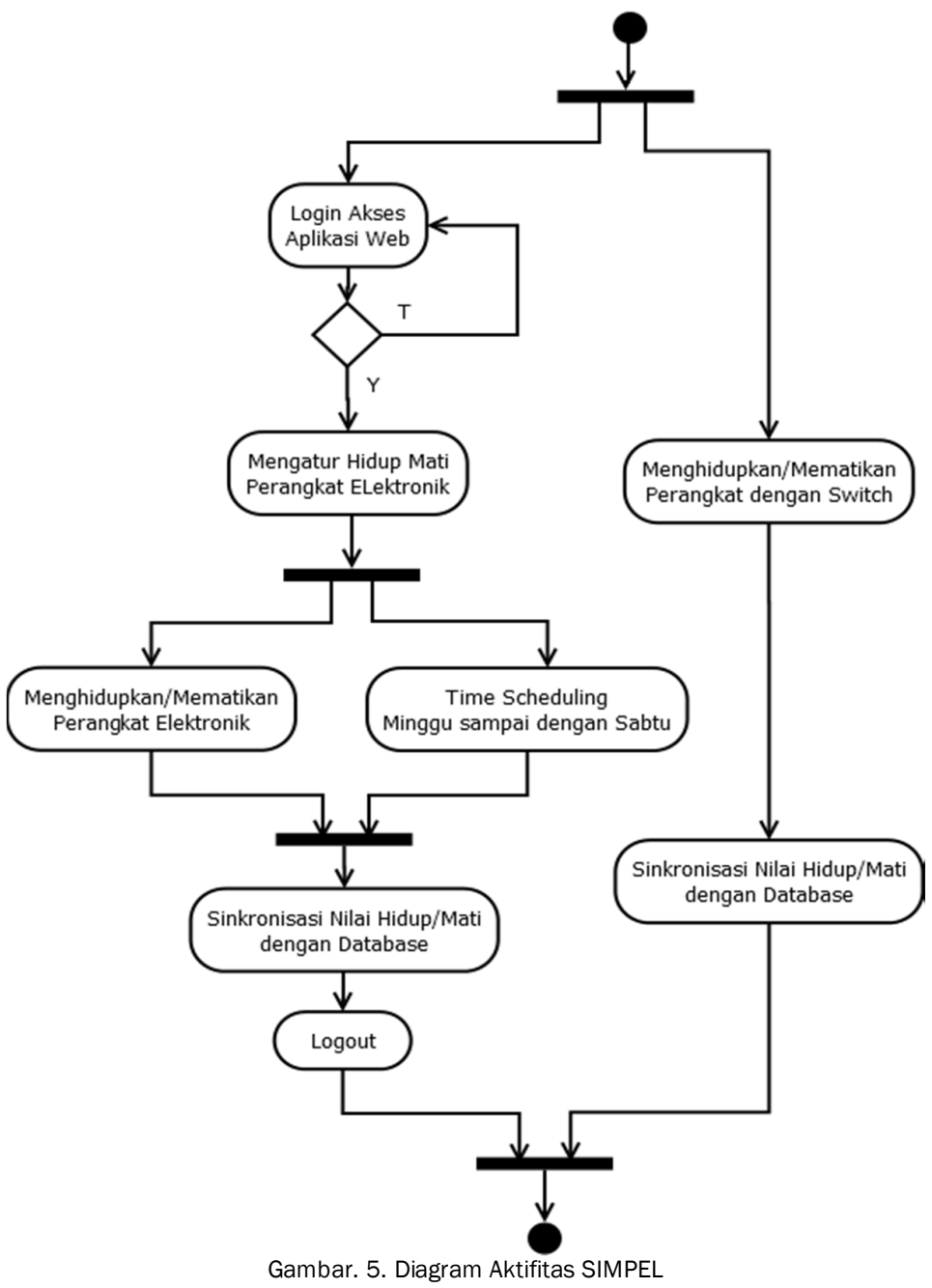

C. Assembling, Coding, dan Testing

Tahapan ketiga yaitu assembling, coding, dan testing. Tahapan ini merupakan tahapan lanjutan dari analisis dan desain. Tahapan ini fokus pada kegiatan merangkai perangkat keras dan membuat perangkat lunak. Kedua kegiatan ini melewati proses testing untuk mengetahui bekerja atau tidaknya integrasi perangkat keras, perangkat lunak, dan jaringan. Beberapa kegiatan tersebut yaitu sebagai berikut :

1) Merangkai Perangkat Keras

Setiap lampu dipasang sakelar dan rangkaian SIMPEL Modul yang di dalamnya terdapat sebuah relay DC5V. Setiap SIMPEL Modul terhubung ke Arduino dan diteruskan ke Raspberry Pi. Dari Raspberry Pi ini nantinya terhubung ke modem. Adapun masing-masing hardware terhubung dengan skema yang ditunjukan pada gambar 6 


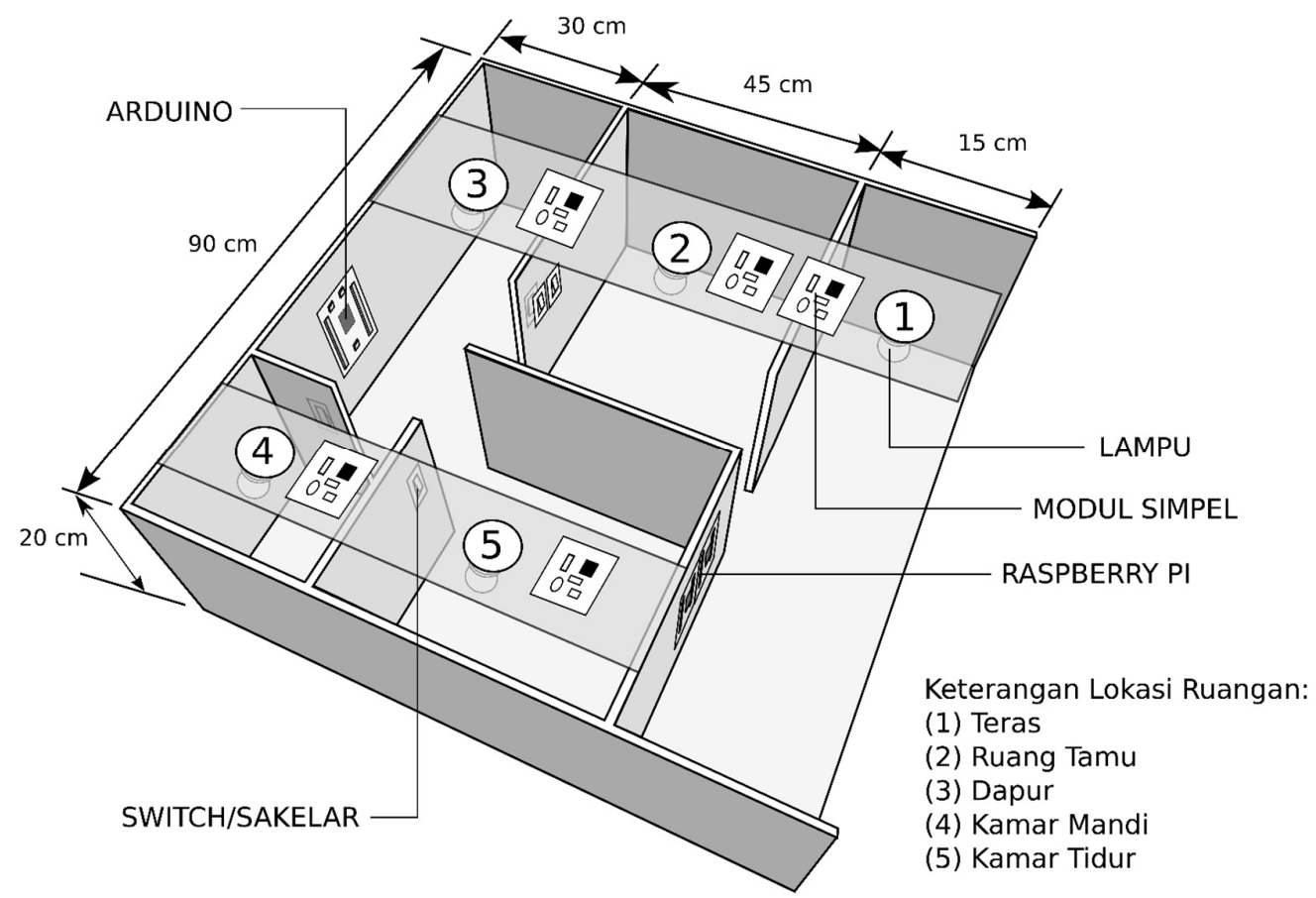

Gambar. 6. Rancangan SIMPEL

2) Membuat Perangkat Lunak

Kegiatan ini meliputi pembuatan aplikasi pada Arduino, Raspberry Pi, dan Aplikasi SIMPEL pada sisi server. Pada Arduino menggunakan bahasa pemrograman Arduino sedangkan pada Raspberry Pi digunakan bahasa pemrograman Python. Sementara itu, pada Aplikasi SIMPEL yang berada pada sisi server digunakan PHP, HTML5, CSS, dan JavaScript. D. Rilis

Setelah melewati tahapan proses assembling, coding, dan testing; Sistem Informasi Manajemen Perangkat Elektronik dengan implementasi miniatur rumah dan aplikasinya dirilis dengan kode SIMPEL versi 1.0. rilis versi 1.0 memuat batasan-batasan dengan tiga peranan penting yaitu kontrol hidup mati perangkat, sinkronisasi data hidup dan mati perangkat dari switch dengan database, dan penjadwalan hidup dan mati perangkat dari hari minggu hingga hari sabtu. Rilis versi 1.0 memungkin sistem untuk dapat dikembangkan lagi sesuai kebutuhan.

IV HASIL DAN ANALISA

Penelitian diimplementasikan pada sebuah miniatur rumah yang terdiri atas 5 buah lampu yang terintegrasi dengan sistem. Lampu tersebut terpasang pada 5 ruangan yaitu teras, ruang tamu, kamar tidur, dapur, dan kamar mandi. Aplikasi sistem ini dapat diakses melalui browser pada komputer atau smartphone. Gambar 7 merupakan tampilan dari aplikasi SIMPEL yang dapat digunakan untuk mengatur dan memonitoring hidup dan matinya perangkat elektronik. Untuk dapat mengakses aplikasi tersebut, pengguna harus memiliki username dan password. 


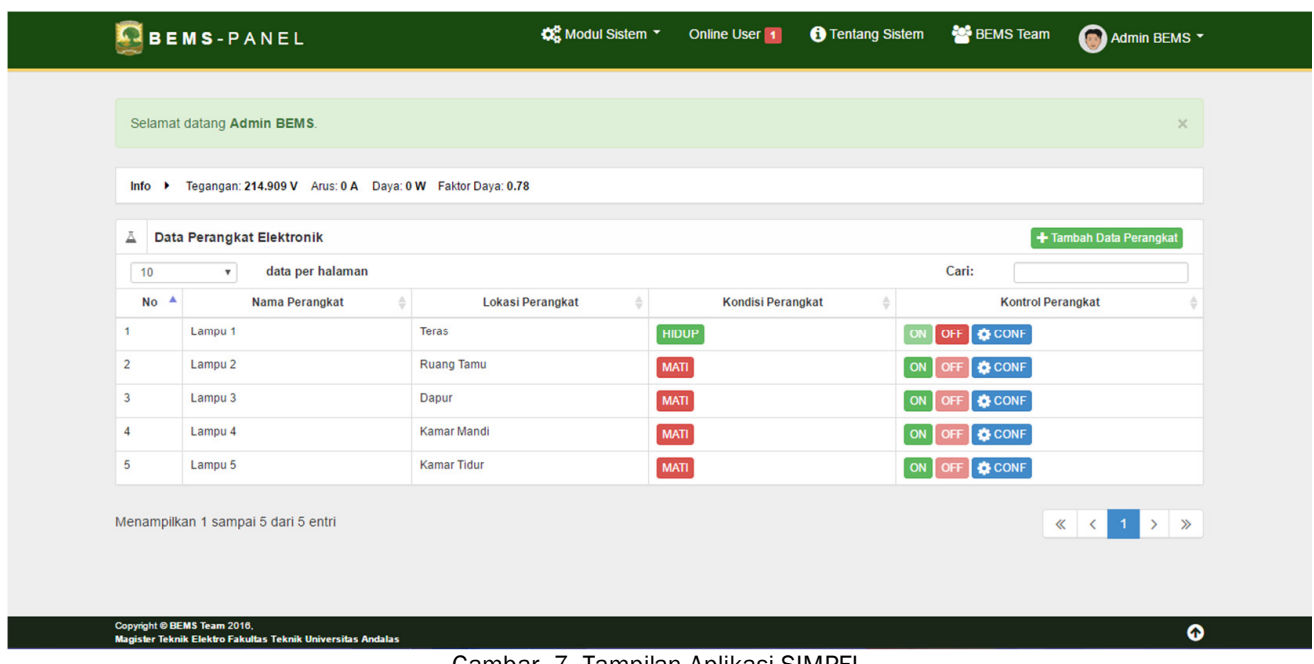

Gambar. 7. Tampilan Aplikasi SIMPEL

Pada aplikasi ini terdapat 5 menu utama yaitu modul sistem (data perangkat dan data pengguna),pengguna online, tentang sistem, tim BEMS, dan nama pengguna BEMS. Data terdiri atas nama pengguna, email, nomor handphone, status online, login terakhir dan logout terakhir. Sedangkan data perangkat terdiri atas nama, lokasi, kondisi, dan kontrol perangkat. Pada kontrol perangkat dapat dilakukan dengan 2 pilihan diantaranya menghidupkan atau mematikan dengan tombol ON/OFF, dan penjadwalan hidup dan matinya perangkat (time scheduling system) dari hari minggu sampai dengan sabtu menggunakan tombol configuration. Selain menggunakan aplikasi ini sistem juga dapat melakukan hidup dan mati perangkat elektronik secara manual dengan sikronisasi sistem dari kontrol sakelar dengan database. Aplikasi ini dapat diakses dengan alamat_http://bems.sunaryo.info melalui browser pada komputer atau smartphone. Pengujian aplikasi telah dilakukan berdasarkan pengaturan hidup dan matinya perangkat diantaranya :

1) Kontrol hidup dan mati perangkat elektronik secara online melalui akses internet

Tabel 1 menampilkan hasil pengujian pada 5 buah lampu yang telah terpasang pada miniatur rumah dan diakses melalui halaman web. Pengguna diberikan hak akses login, selanjutnya dilakukan kontrol hidup dan mati perangkat melalui tombol ON/OFF. Pengujian dilakukan dengan kondisi lampu dalam keadaan mati kemudian dihidupkan dengan mengaktifkan tombol ON. Kondisi lampu saat ini dalam keadaan hidup dan sistem akan menampilkan kondisi hidup pada status perangkat. Database akan melakukan pembaruan data terakhir status perangkat.

TABEL I

Pengujian Kontrol hidup dan Mati Perangkat Secara Online

\begin{tabular}{|c|c|c|c|c|}
\hline Nama Perangkat & Kondisi Awal & Kondisi akhir & Status Aplikasi terakhir & $\begin{array}{c}\text { Keterangan } \\
(\sqrt{ })(\mathbf{X})\end{array}$ \\
\hline Lampu 1 & Mati & Hidup & Hidup & $\sqrt{ }$ \\
\hline Lampu 2 & Mati & Hidup & Hidup & $\sqrt{ }$ \\
\hline Lampu 3 & Mati & Hidup & Hidup & $\sqrt{ }$ \\
\hline Lampu 4 & Mati & Hidup & Hidup & $\sqrt{ }$ \\
\hline Lampu 5 & Mati & Hidup & Hidup & $\sqrt{ }$ \\
\hline
\end{tabular}

2) Penjadwalan hidup dan matinya perangkat dari hari minggu sampai dengan sabtu (Time scheduling system).

Pengujian dilakukan dengan kontrol hidup dan mati perangkat melalui pengaturan waktu pada setiap perangkat dimulai dari hari minggu sampai dengan sabtu. Pengaturan dilakukan pada halaman web BEMS pada tombol conf, selanjutnya ditampilkan kotak dialog seperti pada gambar 8 ini. 


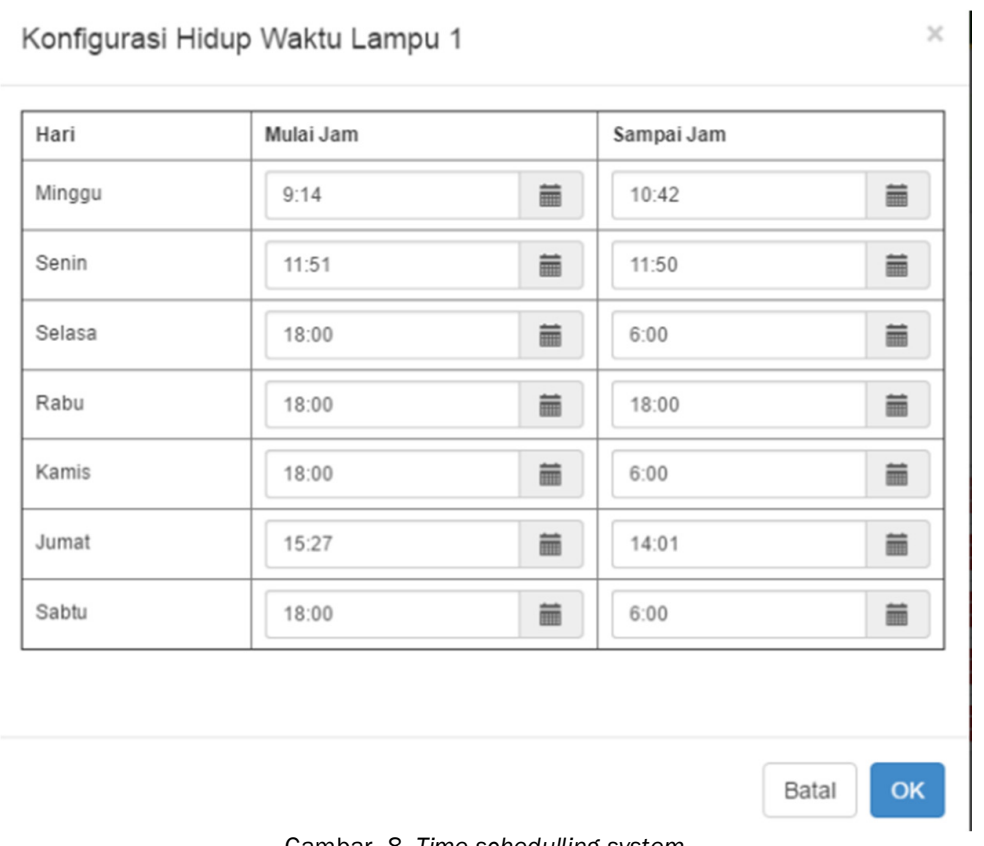

Gambar. 8. Time schedulling system

3) Sikronisasi hidup dan matinya perangkat dari kontrol sakelar

Pengujian ini dllakukan secara manual pada sistem dengan melakukan pengontrolan sakelar yang telah terpasang pada sistem.

\section{KESIMPULAN}

Aplikasi sistem informasi manajemen perangkat elektronik berbasis web ini dapat mengontrol dan memonitoring penggunaan perangkat elektronik di rumah menggunakan smartphone atau komputer. Kontrol hidup mati perangkat dapat dilakukan secara online melalui akses internet, pengaturan waktu penggunaan (time scheduling system) dan sinkronisasi dari kontrol sakelar. Aplikasi SIMPEL memberikan kemudahan dalam mengendalikan perangkat elektronik dari jarak jauh.

\section{REFERENS}

[1] Piyare, R. (2013). Internet of Things: Ubiquitous Home Control and Monitoring System using Android based Smart Phone, 2(1), 5-11.

[2] A. Rajabzadeh, A. R. Manashty, and Z. F. Jahromi, "A Mobile Application for Smart House Remote Control System," World Acad. Sci. Eng. Technol., vol. 62, p. 7, 2010.

[3] S. Panth and M. Jivani, "Home Automation System (HAS) using Android for Mobile Phone," Int. J. Electron. Comput. ..., vol. 3, no. 1, 2013.

[4] A. Amir and M. N. Faisal, "PERALATAN ELEKTRONIK JARAK JAUH BERBASIS WEB," vol. 6, no. 2, pp. 577-584, 2015.

[5] S. Pandikumar and R. S. Vetrivel, "Internet of Things Based Architecture of Web and Smart Home Interface Using GSM," Int. J. Innov. Res. Sci. Eng. Technol., vol. 3, no. 3, pp. 1721-1727, 2014.

[6] R. Shahriyar, E. Hoque, S. M. Sohan, I. Naim, M. M. Akbar, and M. K. Khan, "Remote controlling of home appliances using mobile telephony," Int. J. Smart Home, vol. 2, no. 3, pp. 37-54, 2008.

[7] M. Hneif and S. H. Ow, "Review of Agile Methodologies in Software Development 1," Int. J. Res. Rev. Appl. Sci., vol. 1, no. 1, pp. 2076-734, 2009.

[8] Harleen K. Flora \& Swati V. Chande. A Systematic Study on Agile Software Development Methodologies and Practice. (IJCSIT) International Journal of Computer Science and Information Technologies, Vol. 5(3), 2014, 3626-3637, ISSN: 2076-7366

[9] S. Sharma, D. Sarkar, and D. Gupta, "Agile Processes and Methodologies: A Conceptual Study," Int. J. Comput. Sci. Eng., vol. 4, no. 05, pp. 892-899, 2012. 